\title{
Pollen treatment in high osmotic potential: a simple tool for in vitro preservation and manipulation of viability in gametophytic populations
}

\author{
Leandro Lopes Loguercio
}

Departamento de Ciências Biológicas - DCB, Universidade Estadual de Santa Cruz, Rod. Ilhéus-Itabuna, Km 16, Ilhéus, BA, 45650-000,Brasil; E-mail: leandro@uesc.br

A method for in vitro preservation and manipulation of pollen viability based on simple changes in osmotic potential (sucrose concentrations) in culture media was developed using tobacco pollen as the experimental model. High osmotic potentials were capable of reversibly inhibiting pollen germination, preserving its viability at room temperature for long periods, as assessed by subsequent incubation in germination medium. When pollen was pre-germinated for different periods and subsequently incubated in $80 \%$ sucrose medium (inhibiting medium) there was a progressive decrease in its viability, which was a trend best described by a quadratic regression line. Nevertheless, very small variations in pollentube lengths and viable pollen grains more resistant to the pre-germination step were detected by this procedure. Consequences and potential applications of these findings were discussed for use in analyses of variability, selection in gametophytic populations and pollen storage.

Key words: Gametophytic selection, in vitro pollen germination, Nicotiana tabacum, pollen storage, pollen viability.

Tratamento de pólen em osmolaridade elevada: técnica simples para preservação e manipulação in vitro da viabilidade de populações de gametófitos: Um método para a preservação e manipulação da fisiologia de germinação de pólen foi desenvolvido com base em meras variações na osmolaridade dos meios de cultura, utilizando pólen de tabaco como modelo experimental. Elevadas osmolaridades foram capazes de inibir a germinação de pólen, mas também de preservar sua viabilidade à temperatura ambiente por longo período de tempo, como demonstrado pela posterior incubação em meio de germinação. Quando pólen foi pré-germinado por diferentes períodos, seguido de incubação em meio com $80 \%$ de sacarose (inibição), um decréscimo progressivo na viabilidade foi observado, sendo essa tendência melhor descrita por uma curva de regressão quadrática. Contudo, este procedimento permitiu observar pequenas variações no comprimento de tubo-polínico, além da deteç̧ão de grãos de pólen viáveis que foram resistentes à pré-germinação. As conseqüências e potencial aplicabilidade dessas observações foram discutidas quanto a análises de variabilidade e seleção em populações de gametófitos, bem como quanto ao armazenamento de pólen.

Palavras-chave: Armazenamento de pólen, germinação de pólen in vitro, Nicotiana tabacum, seleção gametofítica, viabilidade de pólen.

Selection on male gametophytes (pollen) to alter the genetic constitution of the subsequent sporophytic generation has been suggested as an interesting tool in plant breeding programs (Hormaza and Herrero, 1992), based on the likelihood that selection of gametophytes has actively participated in the evolution of angiosperms (Mulcahy, 1979) and on the significant similarity of gene expression found between the diploid and haploid phases (Tanksley et al.,
1981; Pedersen et al., 1987). In this context, a method allowing easy and reliable scoring of the genetic and/or environmental variability in pollen samples would be very useful (Vasil, 1987).

In vitro germination of mature pollen grains has been widely developed in several species as a convenient way to investigate basic and applied aspects of gametophytic biology (Taylor and Hepler, 1997). For example, studies 
on the pollen germinative behavior revealed genetic differences among genotypes (Pfahler et al., 1997) and sporophytic traits of interest appeared to be associated with the timing of germination and speed of gametophytic growth (Hormaza and Herrero, 1992). Distinct media for adequate pollen germination have been established for many different species and purposes (e.g. Ylstra et al., 1992; Loupassaki et al., 1997; Adhikari and Campbel 1998), although all of them display the common characteristic of allowing nonstop pollen-tube growth, which generates a mass of long and intertwined tubes (Shivanna and Sawhney, 1995) that hampers three follow-ups that are often necessary, but not easily achieved: (i) the possibility of assessing very small differences in the germination timing and speed of growth of individual grains (Shivanna and Sawhney, 1995); (ii) the use of treated and/or germinated gametophytes for further in vivo pollination (Hormaza and Herrero, 1992); and (iii) the storage and shipment of viable pollen for crosses among plants in different locations (Lansac et al., 1994; Bajaj, 1987). Hence, the opportunity of in vitro manipulation of pollen germination and viability would circumvent those problems and provide an interesting tool for further studies.

An appropriate medium osmotic potential (Vasil, 1987; Shivanna and Sawhney, 1995) determines the productive (re)hydration and (re)activation of the pollen-germinative metabolism (Heslop-Harrison, 1987; Crowe et al., 1989), thus playing a key role for high levels of germination. Using tobacco pollen as the experimental system, the effects of simple changes in the osmotic potential of the incubating medium were tested. Flowers of greenhousegrown Nicotiana tabacum L. cv. "Maryland Mammoth" plants were cut off one day before anthesis and UV sterilized for $30 \mathrm{~min}$, and kept in sterile Petri dishes at room temperature $\left(\sim 26^{\circ} \mathrm{C}\right)$ until the natural opening of petals and anthers. The pollen grains were collected by gently shaking the flowers onto a sterile dish and pooling the grains into one $1.5 \mathrm{~mL}$ tube using a soft brush. Pollen samples for use in the experiments were stored at $4{ }^{\circ} \mathrm{C}$ for up to 5 days without loss in the original viability. The standard pollen germination medium $(\mathrm{GM})$ was $1.27 \mathrm{mM} \mathrm{Ca}\left(\mathrm{NO}_{3}\right)_{2} \cdot 4 \mathrm{H}_{2} \mathrm{O}$, $0.87 \mathrm{mM} \mathrm{MgSO}_{4} \cdot 7 \mathrm{H}_{2} \mathrm{O}, 0.99 \mathrm{mM}$ of $\mathrm{KNO}_{3}, 1.62 \mathrm{mM} \mathrm{H}_{3} \mathrm{BO}_{3}$ and $10 \%$ sucrose $(\mathrm{w} / \mathrm{v}), \mathrm{pH} 7$ (Brewbaker and Kwack, 1963). Media with altered sucrose concentrations always contained the same amounts of these salts.

Pollen was incubated in $1 \mathrm{~mL}$ of liquid media at room temperature. A standardized amount of $1 \mathrm{mg} \cdot \mathrm{mL}^{-1}$ of pol- len was used per treatment, in a single experiment; each sucrose concentration tested (see table 1) or each time point of pre-incubation in GM, for each inhibition period (see figure 2) was a treatment. Single experiments were repeated four times to obtain the averages and standard deviations. For $16 \mathrm{~h}$ germination-recovery cultures, pollen was transferred to liquid GM and poured on a $1 \mathrm{~mL}$ GM medium partially solidified with $0.3 \%$ agar (w/v), in $3.5 \times 1.7 \mathrm{~cm}$ Petri dishes. Pollen was switched between media with different osmotic potentials as follows: from lower to higher osmotic potential, the samples were centrifuged at 3,000 rpm in a microcentrifuge for 1-2 min, the supernatant was removed, and the grains were thoroughly re-suspended in $1 \mathrm{~mL}$ of higher-osmotic potential medium; from higher to lower osmotic potential, proper dilutions were performed with GM salts solution, followed by centrifugation at 3,000 rpm in a bench-top swing-bucket centrifuge for 1-2 min in $15 \mathrm{~mL}$ tubes, and re-suspension of grains in $1 \mathrm{~mL}$ of GM.

Pollen germination and growth were assessed by light microscopy. For statistically adequate sampling, the treatment germination percentage was taken as the average of five observations, each corresponding to a random microscope field with more than 50 grains on the Petri dish focused. Pollen-tube lengths were determined as the average of 15 randomly chosen tubes per treatment. Tubes were measured either by microscope-attached vernier or by equivalence to the number of diameters of a non-germinated grain (one diameter $=30 \mu \mathrm{m}$ ). One diameter was the minimum tube length used to consider a grain as germinated. Common statistical procedures were used for fitting linear and non-linear regressions (Snedecor and Cochran, 1969).

The effects of a broad range of sucrose concentrations (osmotic potential) were assessed on the in vitro tobacco pollen germination (table 1). In agreement with previous studies (Tupy et al., 1983; Ylstra et al. 1992), around $10 \%$ sucrose provided the most appropriate osmotic potential for rapid pollen germination, yielding grains with well-rounded morphology (figure 1A), which developed fully elongated tubes (figure 1B). Inversely, osmotic conditions above and below the optimum reduced germination percentages and pollen-tube lengths (table 1), although the aspect of the grains was different under light microscope. Low osmotic potential, i.e. high water potential, led to integral grains with a slightly shrunken morphology and apparently denser protoplasm (figure 1C) and to a high pro- 
portion of burst pollen (data not shown). These effects were probably due to a too rapid influx of water in the grains, causing excessive leakage of endogenous soluble substances and ions, a phenomenon known as 'imbibition damage' (Crowe et al., 1989). This inadequate re-hydration caused poor reorganization and integrity of the pollen membranes and metabolism (Heslop-Harrison, 1987; Hoekstra et al., 1992), and the gametophytic viability was thereby decreased. On the other hand, incubation at higher osmotic potential rendered a distinct 'desiccated-like' grain morphology (Figure 1D), but more importantly, it led to a reversible inhibition effect of the in vitro pollen germination. Media with high sucrose contents during $24 \mathrm{~h}$ allowed the preservation of pollen viability. Higher osmotic potentials showed progressively better preservation effects (table 1). GM-salt medium with $80 \%$ sucrose performed best in protecting gametophytic viability, as regular levels of in vivo germination recovery and fertilization (data not shown) were achieved after an extended inhibition period of $56 \mathrm{~h}$. These results suggest that media with highly increased osmotic potential induce a very slow (or null) water uptake by pollen grains. Thus, the reactivation of the germinative metabolism could have been greatly slowed down, thereby generating the observed viability-preservation effect (table 1)

Considering this reversible-inhibition effect on pollen germination (table 1), this procedure could be employed for gametophytic selection if a given treatment applied directly to the high-osmotic medium proved to be effective as a selective factor. For example, if gametophytes exposed to a specific compound (e.g. Ravikumar and Chikkodi, 1998) included in the inhibition medium responded differently to this treatment, then, after the inhibition period, the resistant grains would germinate faster and/or longer than sensitive ones. The transmission of desirable genes, therefore, would be favored in subsequent in vivo pollination (Hormaza and Herrero, 1992). Obviously, further experiments are required to assess the effectiveness of a diverse array of selective factors to gauge the real potential of this technique for in vitro gametophyte treatment and selection.

Another aspect of this reversible-inhibition procedure is the possibility of using it to manipulate shortand long-term pollen preservation. For example, since viability could be held at room temperature for more than two days (see above), one may consider using reversible inhibition of pollen to facilitate its transportation to pollinate plants in distant geographical locations (Lansac

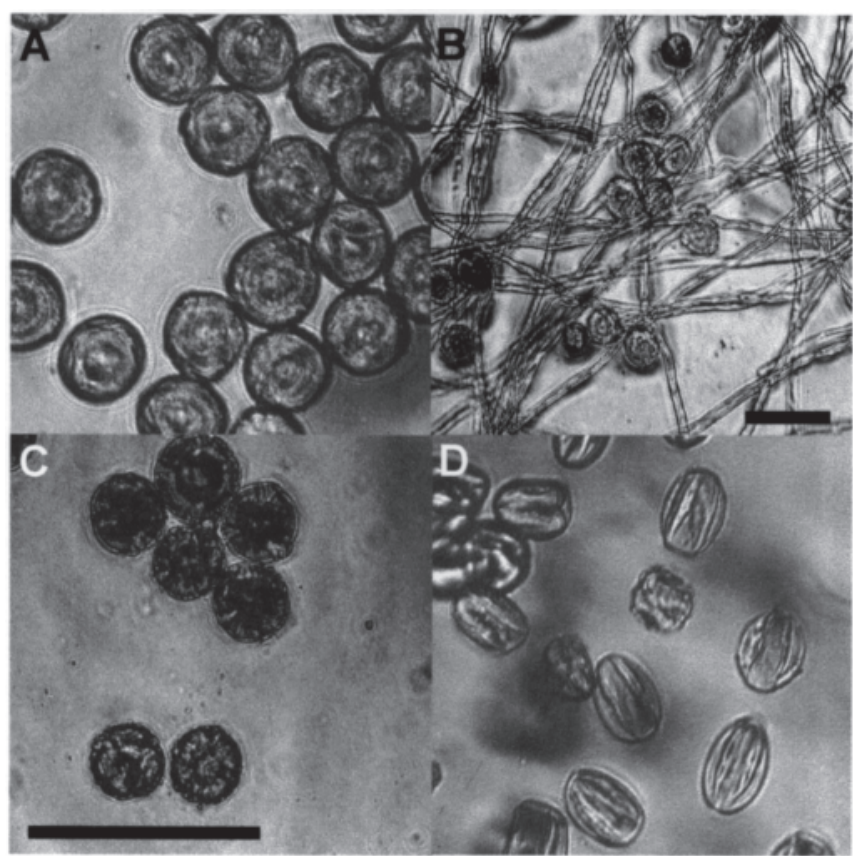

Figure 1. Light microscopy of tobacco pollen morphology under varying conditions of medium osmotic potential. Grains in 10\%-sucrose GM after 2 min (A) and after $2 \mathrm{~h}$ incubation (B); grains in GM salts $+2 \%$ sucrose $(\mathrm{C})$ and in GM salts $+80 \%$ sucrose (D), both after $2 \mathrm{~h}$ incubation. All incubations were performed at room temperature. Bars $=0.1 \mathrm{~mm}$; micrographs in (A), (C) and (D) have the same magnification.

et al., 1994). Alternatively, the combination of an inhibitory medium with very low temperatures, normally used for long-term pollen storage (Bajaj, 1987), may be useful for pollen 'vitrification' (Santos, 2000), and thus gametophytic viability preservation for much longer periods of time. This would allow pollen storage and shipment for fertilization of plants with distinct flowering times and/or located overseas, a frequently necessary procedure in international cooperative breeding programs

Because very high osmotic potentials preserved pollen viability when grains were initially non-germinated, a 'sequential-incubation' procedure was tested to verify whether this effect also held true for pre-germinated grains. Pollen was pre-incubated in GM (10\% sucrose) for different periods, transferred to GM salts $+80 \%$ sucrose medium for 24 and $48 \mathrm{~h}$ (inhibition), and re-incubated in GM for analysis of germination recovery. The results showed that prolonged pre-germination caused proportional decreases in viability (figure 2). These results indicate that 
Table 1. Effects of varying osmotic potential (sucrose concentration) in germination medium salts on pollen germination and tube growth.

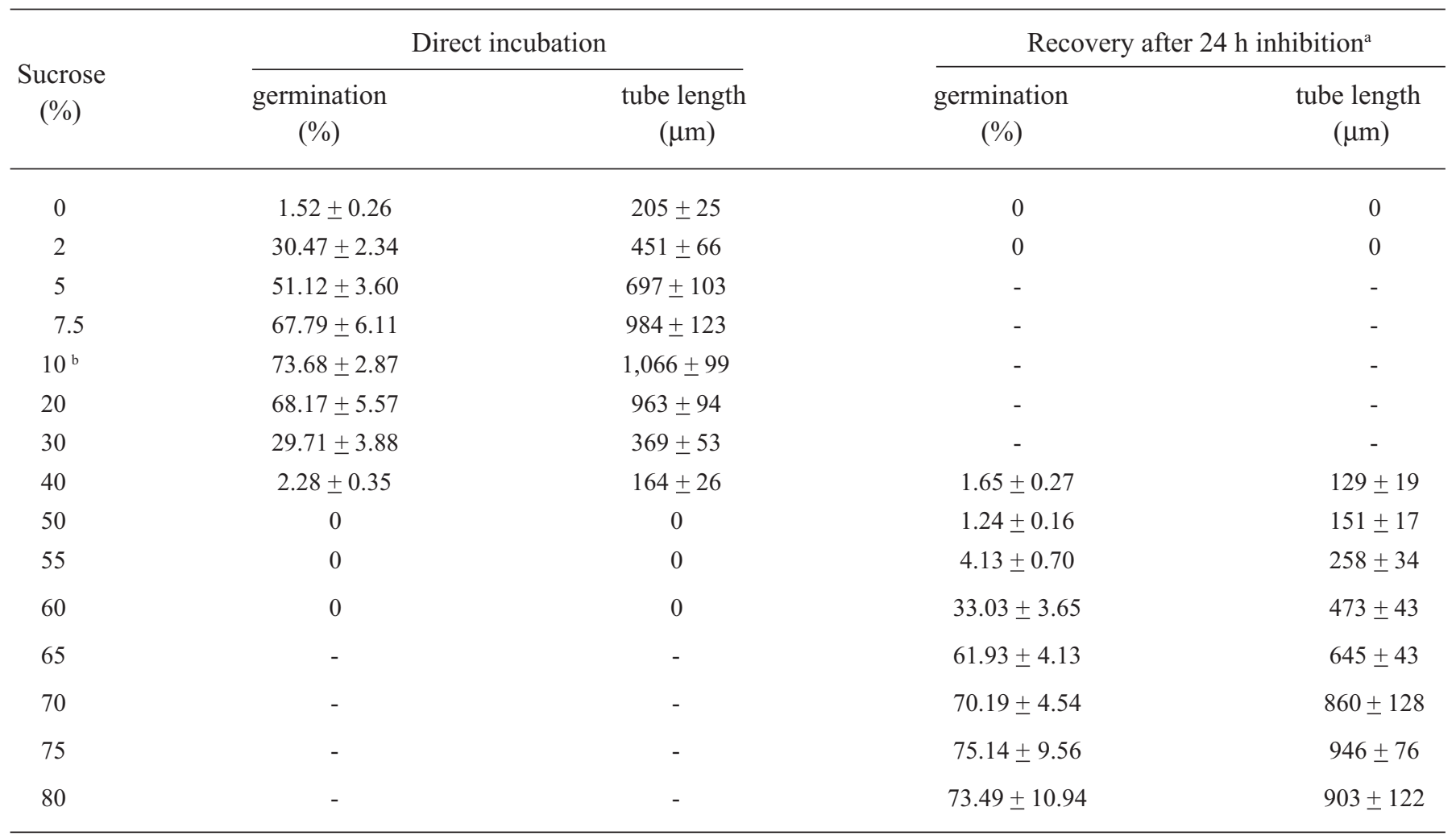

a Analysis of the in vitro pollen germination recovery was performed in regular GM containing $10 \%$ sucrose, after a $24-\mathrm{h}$ incubation at room temperature in media with GM salts plus the sucrose concentrations indicated on the left column.

${ }^{\mathrm{b}}$ Corresponded to the 'control' treatment for baseline $\%$ of germination of samples, for all experiments.

the approach of reversibly inhibiting mature (desiccated) pollen cannot be extended to pre-germinated gametophytes. It appears that, once the germinative metabolism is reactivated, it cannot be halted by changes in medium osmotic potential without negatively affecting the viability, thereby limiting the recovery of gametophytes capable of in vivo fertilization. However, such a sequential incubation showed an interesting ability: the detection of individual gametophytes in a population that are resistant to this activationinhibition process, as shown by the fully elongated pollen tubes observed (figure 3 ). This probably reflects a delay in the onset of germination, and thus a quiescent metabolism during the inhibition period. Therefore, these late-germinating gametophytes might be chosen for selection in a situation where such a characteristic proves to be associated with certain sporophytic phenotype(s) of interest. To illustrate this concept, some evolutionary studies revealed that fast pollen germination is often traded off with survival,

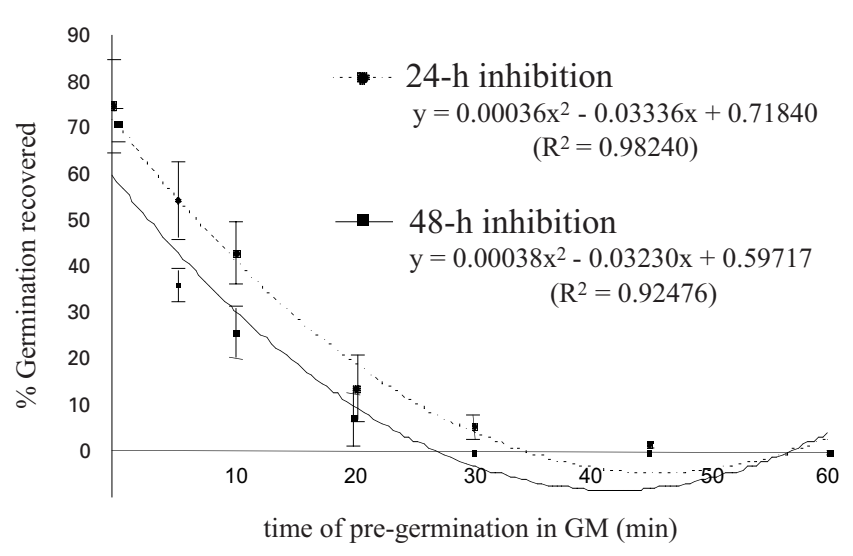

Figure 2. Pollen germination recovered after different periods of pre-germination in GM, followed by 24 and 48 $\mathrm{h}$ periods of inhibition in GM salts $+80 \%$-sucrose medium, all at room temperature. Error bars estimate the deviation in four replications of the experiment. As a control for pollen sample germination, $1 \mathrm{mg} \cdot \mathrm{mL}^{-1}$ of the same pollen sample was incubated directly in GM for $16 \mathrm{~h}$, with a $\%$ of germination of $74.4 \pm 3.6$. 


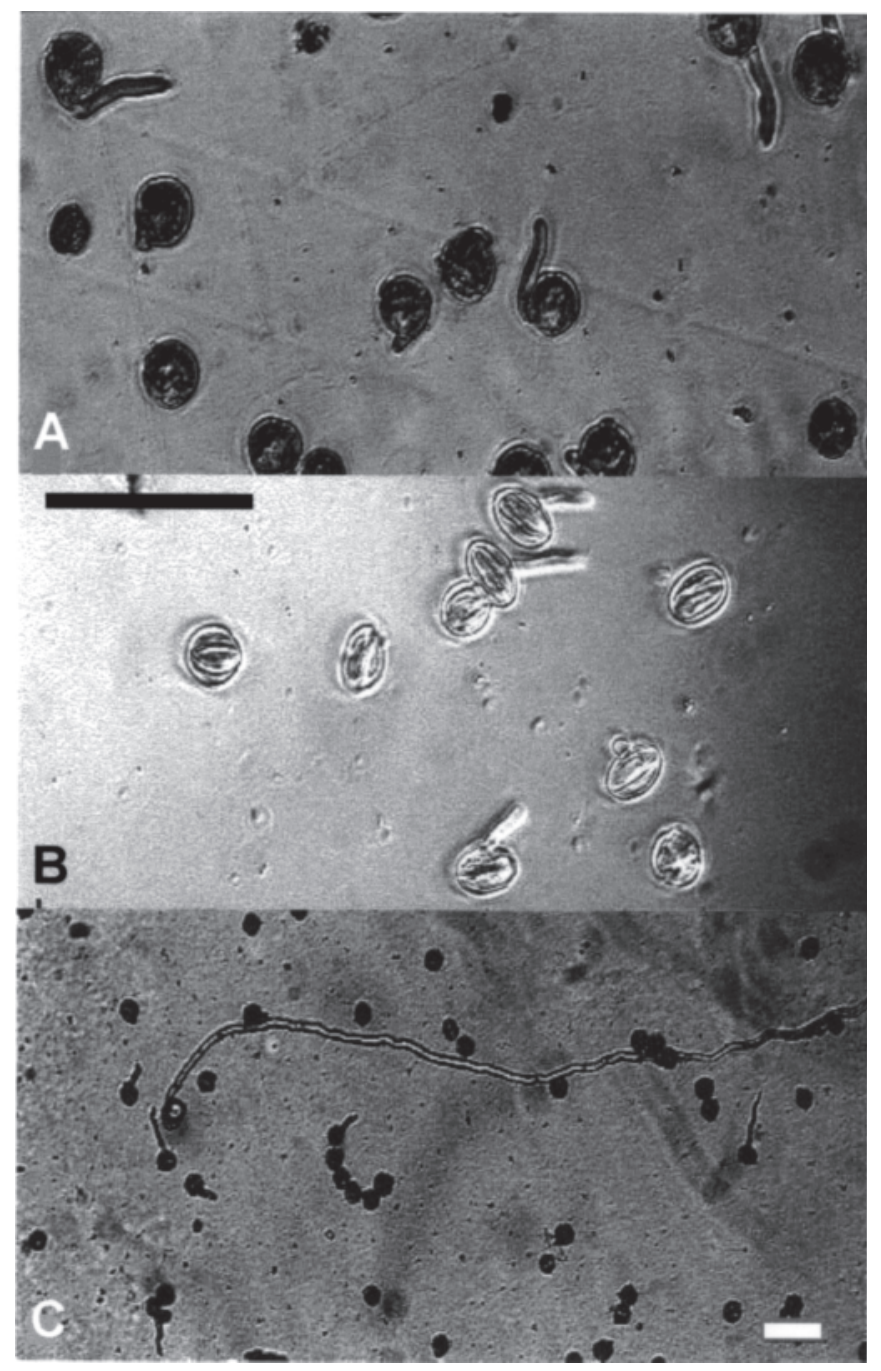

Figure 3. Light micrograph of pollen after $20 \mathrm{~min}$ pre-germination in liquid GM (A), displaying small differences in tube elongation on a grain-to-grain basis; same pollen in GM salts $+80 \%$-sucrose inhibitory medium after $24 \mathrm{~h}$ (B); same pollen after germination-recovery incubation in $0.3 \%$ agar GM (C), showing a fully elongated pollen tube. Bars $=0.1 \mathrm{~mm}$.

i.e. better fitness in adverse conditions would be linked to late-germination gametophytes (Dajoz et al., 1991). Moreover, if one takes into account that some sporophytic traits of interest appeared to be directly associated with germination timing and gametophyte growth speed (Hormaza and Herrero, 1992), the "freezing" of gametophytic development caused by the sequential-incubation procedure not only prevented the undesired intertwining of excessivelygrown pollen tubes (Shivanna and Sawhney, 1995), but also allowed the observation of very small differences in tube lengths. Hence, for gametophytic selection purposes, the population variability regarding the differential time response of individual grains to re-hydration and metabolism reactivation can be easily and reliably assessed.

To provide a mathematical description for the behavior displayed by pollen subjected to this sequential incubation, a regression analysis was performed for each set of data corresponding to the $24 \mathrm{~h}$ and $48 \mathrm{~h}$ inhibition periods. A second-degree (quadratic) polynomial regression provided the best-fitting model to describe the trends shown in the graph, with determination coefficients $\left(\mathrm{R}^{2}\right)$ above 0.92 in both sets (figure 2); the continuation of the trend lines below the $\mathrm{X}$ axis was a mere calculation artifact with no biological meaning. Although the absolute decreasing effect on pollen viability appeared clearly stronger for the $48 \mathrm{~h}$ inhibition period, it is striking that the second- and first-degree terms in both trend-line equations were of a fairly similar magnitude (figure 2). Since the pollen used in these experiments came from a single genetic source, it is tempting to speculate that such similar equation coefficients might reflect a characteristic genotypic constitution of the gametophytic populations. Therefore, the quadratic regression of sequential pollen incubation might work as a 'fingerprinting' technique to allow comparisons among gametophytic samples from different genotypic sources and be used for selection purposes either on the current generation of gametophytes or on the previous generation of sporophytes (see above). Steeper lines would indicate a gametophytic population with a higher proportion of grains that germinate earlier, whereas smoother curves would indicate the opposite.

This study demonstrated that simple manipulation of in vitro water uptake by the mature gametophyte was enough to alter the physiology of the tobacco pollen germination. By studying and adapting this whole rationale for other species, specific conditions of media composition and osmotic types and concentrations and incubation periods are likely to be found for reversible inhibitory effect and for use in the sequential-incubation procedure. It is obvious that further in-depth investigations are certainly necessary to test all the possibilities and conjectures discussed here. In any case, it is hoped that the simple and inexpensive methodology presented in this study can be fruitfully employed in several aspects of pollen biology research and plant breeding of other species. 
Acknowledgments: Thanks are due to professors Hélio M. M. Maia, Regina R. Termignoni, Fernando Z. Cruz and João R. Jardim Freire (UFRGS) for laboratory and equipment support. I also thank Sidney N. Parentoni, Thales L. Rocha and Marcelo A. Fontes (CNPMS/EMBRAPA) for helpful comments in the manuscript. This work was funded by CNPq/Brazil.

\section{REFERENCES}

Adhikari KN, Campbell CG (1998) In vitro germination and viability of buckwheat (Fagopyrum esculentum Moench) pollen. Euphytica 102:87-92.

Bajaj YPS (1987) Cryopreservation of pollen and pollen embryos, and the establishment of pollen banks. Int Rev Cytol. 107:397-420.

Brewbaker JL, Kwack BH (1963) The essential role of calcium ion in pollen germination and pollen tube growth. Am. J. Bot. 48:457-469.

Crowe JH, Hoekstra FA, Crowe LM (1989) Membrane phase transitions are responsible for imbibitional damage in dry pollen. Proc. Natl. Acad. Sci. USA 86:520-523.

Dajoz I, Till-Bottraud I, Gouyon P-H (1991) Evolution of pollen morphology. Science 253:66-69.

Heslop-Harrison J (1987) Pollen germination and pollentube growth. Int. Rev. Cytol. 107:01-78.

Hoekstra FA, Crowe JH, Crowe LM (1992) Germination and ion leakage are linked with phase transitions of membrane lipids during imbibition of Typha latifolia pollen. Physiol. Plant. 84:29-34.

Hormaza JI, Herrero M (1992) Pollen selection. Theor. Appl. Genet. 83:663-672.

Lansac AR, Sullivan CY, Johnson BE, Lee KW (1994) Viability and germination of the pollen of sorghum $\{$ Sorghum bicolor (L.) Moench\}. Ann. Bot. 74:27-33.

Loupassaki M, Vasilakakis M, Androulakis I (1997) Effect of pre-incubation humidity and temperature treatment on the in vitro germination of avocado pollen grains. Euphytica 94: 247-251.
Mulcahy DL (1979) The rise of angiosperms: a genecolical factor. Science 206:20-23.

Pfahler PL, Pereira MJ, Barnett RD (1997) Genetic variation for in vitro sesame pollen germination and tube growth. Theor. Appl. Genet. 95:1218-1222.

Pedersen S, Simonsen V, Loeschcke V (1987) Overlap of gametophytic and sporophytic gene expression in barley. Theor. Appl. Genet. 75:200-206.

Ravikumar RL, Chikkodi SB (1998) Association between sporophytic reaction to Alternaria helianthi and gametophytic tolerance to pathogen culture filtrate in sunflower (Helianthus annuus L.). Euphytica 103:173-180.

Santos IRI (2000) Criopreservação: potencial e perspectivas para conservação de germoplasma vegetal. Rev. Bras. Fisiol. Veg. 12(ed. especial):70-84.

Shivanna KR, Sawhney VK (1995) Polyethylene glycol improves the in vitro growth of Brassica pollen tubes without loss in germination. J. Exp. Bot. 46:1771-1774.

Snedecor GW, Cochran WG (1969) Statistical methods. Iowa State University Press, Iowa.

Tanksley SD, Zamir D, Rick CM (1981) Evidence for extensive overlap of sporophytic and gametophytic gene expression in Lycopersicum esculentum. Science 213:453-455.

Taylor LP, Hepler PK (1997) Pollen germination and tube growth. Annu. Rev. Plant Physiol. Plant Mol. Biol. 48:461-491.

Tupy J, Hrabètová E, Càpková V (1983) Amino acids and bivalent cations in the growth of tobacco pollen in mass culture. Plant Sci. Lett. 30:91-98.

Vasil IK (1987) Physiology and culture of pollen. Int. Rev. Cytol. 107:127-174.

Ylstra B, Touraev A, Benito-Moreno RM, Stöger E, van Tunen AJ, Vicente O, Mol JNM, Heberle-Börs E (1992) Flavonols stimulate development, germination, and tube growth of tobacco pollen. Plant Physiol. 100:902-907. 